\title{
Seasonal prevalence of Asian honeybee ectoparasitic mite Varroa destructor Anderson and Trueman, 2000 in Madanpokhara Apiaries, Palpa, Nepal
}

\author{
Nripesh Shrestha ${ }^{1}$ | Ishan Gautam ${ }^{2 *}$ (D) \\ ${ }^{1}$ Tri-Chandra Multiple Campus, Tribhuvan University, Kathmandu, Nepal \\ ${ }^{2}$ Natural History Museum, Tribhuvan University Kathmandu, Nepal \\ *Correspondence: is_gautam@rediffmail.com \\ Received: 14 July 2020 | Revised: 07 August 2020 | Accepted: 09 August 2020
}

\begin{abstract}
The present study highlights the prevalence and seasonal variation of Varroa destructor Anderson and Trueman, 2000 in Apis cerana colonies at two apiaries (site-I and site-II) in Madanpokhara, Palpa district, Nepal. Altogether 498 varroa mites were collected from February to October 2017. The highest and lowest number of varroa mites were observed in March and September, respectively. The mites were observed higher in brood cells $(54.84 \%$ and $52.51 \%)$ and lower in adult bees (10.39\% and $9.59 \%)$ in site-I and site-II, respectively. The inner hive and outer temperature in site-I and II were ranged from $30^{\circ} \mathrm{C}$ to $34^{\circ} \mathrm{C}$ and $24^{\circ} \mathrm{C}$ to $32.4^{\circ} \mathrm{C}, 30^{\circ} \mathrm{C}$ to $33.5^{\circ} \mathrm{C}$ and $25.1^{\circ} \mathrm{C}$ to $32.3^{\circ} \mathrm{C}$, respectively. Similarly, inner and outer hive humidity ranged from $41 \%$ to $61 \%$ and $40 \%$ to $68 \%, 40 \%$ to $60 \%$ and $41 \%$ to $65 \%$ at site-I and II respectively, differed significantly and correlated positively with mite population. Concern for honeybee health and conservation along with Nepali apiculture are also discussed in this paper.
\end{abstract}

Keywords: Apis cerana, Climatic factors, Honeybee, Population variations, Varroa mite

\section{1 | Introduction}

The ectoparasitic honeybee mite Varroa destructor Anderson and Trueman, 2000 is primarily confined to the Asian honeybee Apis cerana, which is also one of the most important causes of colony failures in the European honeybee A. mellifera (Sanford et al. 2007). The Asian honeybee affected by the other species $V$. jacobsoni, switched to $A$. mellifera causes its colonies decline. Originally $V$. destructor was described from $A$. cerana as well as the new host $A$. mellifera which as previously known as $V$. jacobsoni (Anderson 2000, Anderson \& Trueman, 2000). There are eighteen haplotypes among $V$. jacobsoni throughout the Asian mainland (Anderson \& Trueman 2000), one of them is the $V$. destructor identified as a distinct species which is also reported from Nepal (Anderson \& Trueman 2000, Neupane 2009, Shrestha et al. 2020). Adult varroa mites contribute as new transmission routes of some naturally harmless honeybee viruses (Sumpter \& Martin 2004). Nevertheless, V. destructor has been infesting colonies leading to failures, attributive to viruses and described as bee parasitic mite syndrome (Shimanuki et al. 1994). It is a vector of honeybee viruses by sucking hemolymph of pupae and adults from one host and then inject viruses into another healthy individual in phoretic life stage (Ball, 1989), spread the viruses rapidly (Bernardi \& Venturino 2016), trigger high virus load (Tentcheva et al. 2004), virus replication through penetrating cuticle or by injecting external proteins into the insect hemolymph (Dandeu et al. 1991). Some empirical evidences are available highlighting impacts of varroa mites on brood, hive bees and foragers (Khoury et al. 2011) especially $V$. destructor in workers and drones populations (Tentcheva et al. 2004, Maidana et al. 2005, Jamshidi et al. 2009, Neupane 2009) including prevalence and reproduction of Tropilaelaps mercedesae and $V$. destructor in A. mellifera (Buawangpong et al. 2015, Shrestha et al. 2020). Low varroa mite infestations can reduce the expression of antimicrobial peptides, reduce immunity function, facilitate virus amplification, and also affect behavior (Gregory et al. 2005, Yang \& Cox-Foster, 2005, Navajas et al. 2008). High infestation can lower pupal and adult weight, reduce reproductive ability of drones and foraging capabilities of workers (Bowen-Walker \& Gunn 2001, Duay et al. 2003) which may increase sensitivity to insecticides through lowering the titer of vitellogenin in the hemolymph of infested bees (Amdam et al. 2004). 
The rapid spread of $V$. destructor in $A$. mellifera colonies is one of the main causes of colony failures. The varroa mite is widespread in Europe, North Africa, the Americas, and Asia. The colony death occurs in two years if the mite infestation is not controlled by acaricide treatments (Bernardi \& Venturino 2016). In Nepal, another honeybee mite T. clareae was noticed in $A$. mellifera and $A$. dorsata colonies whereas $V$. destructor was observed in $A$. cerana and $A$. mellifera colonies in Chitwan considering threat to $A$. cerana bees in the Nepalese context (Neupane 2009, Shrestha et al. 2020). Also, a collection of $V$. jacobsoni from the nest of $A$. cerana from Nepal yielded a new species, V. underwoodi (Delfinado-Baker \& Aggarwal 1987).

In Nepal, the activities such as importation of queen bees from varroa mite infested areas, movement of infested colonies for pollination purpose have admitted rapid spread of mites, diseases and pests (Neupane 2009). Unchecked mite infestation leads to

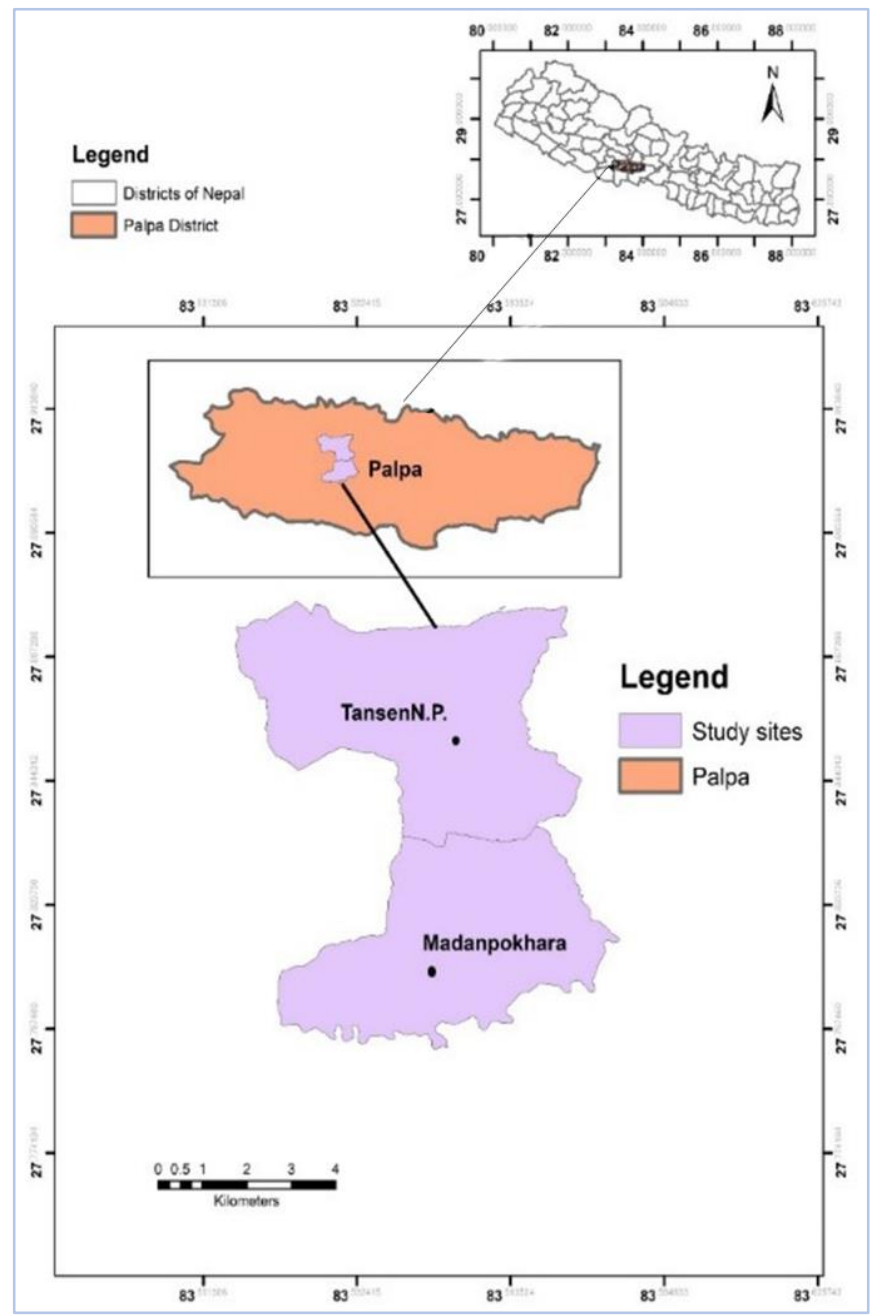

Figure 1. Map of the study area colony collapse. Despite this fact, the study on the prevalence and seasonal variations of $V$. destructor on honey bee colonies are scanty in Nepal. Therefore, spread of several viruses through varroa parasitism which may have deleterious effects such as mortality and decline of honeybee colonies strongly necessitate this study. The present study reports the prevalence and seasonal occurrence of $V$. destructor in the apiaries of Palpa district, Nepal.

\section{2 | Materials and methods}

\section{1 | Study area}

This study was conducted in Madanpokhara of Tansen Municipality, Palpa district, Nepal (Fig. 1). The elevation and climate vary from $213 \mathrm{~m}$ (tropical) to $1900 \mathrm{~m}$ (subtropical). The average maximum and minimum temperature recorded was $31.02^{\circ} \mathrm{C}$ in June and $6.56^{\circ} \mathrm{C}$ in January. The district receives average annual rainfall of $0 \mathrm{~mm}$. to $388.72 \mathrm{~mm}$. Study was conducted at two different established and managed apiaries (site-I and site-II) having 20 beehives each. Both sites (I and II) were two kilometers apart, lying between $27^{\circ} 34^{\prime}-27^{\circ} 57^{\prime} \mathrm{N}$ and $83^{\circ} 15^{\prime}-83^{\circ} 22^{\prime} E$. An apiary at site-I possessed two years old bee hives and another site-II had both old and new bee hives.

\section{2 | Data collection}

Sampling was carried from February to October 2017. Mites were collected from both worker and drone cells and base, brood and adult honeybees during $10 \mathrm{AM}$ to $4 \mathrm{PM}$. The debris presented on the bottom board of bee hive was collected regularly and was floated in 70 percent alcohol. The mites and pieces of chitin floated while wax and other heavy materials were drained off in separate petri dishes and the mite species were picked up with the help of a fine camel hair brush (Ritter \& Ruttner 1980). Analysis of brood mites was performed by examining 50-100 capped brood cells of both drone and worker bees with perforations caps or sunken caps (Aggarwal 1988, Wongsiri et al. 1989). Adult honeybee mites were examined by direct visual observation in every frame of the hive. The thorax and legs of honeybees were carefully noticed and mites were collected using brush and forceps. Permanent slides of the mites were prepared and were deposited at Natural History Museum, Tribhuvan University. The outside (ambient) and inside hive temperature and outside (atmospheric) along with inside hive relative humidity of each hives were recorded using Thermohygrometer HTC-01. 


\section{3 | Identification of the mite}

Out of eighteen haplotypes of $V$. jacobsoni reported, haplotypes from Nepal, China, Thailand, Vietnam, and Japan are known as V. destructor. In original description of Anderson and Trueman (2000) it is morphologically similar to $V$. jacobsoni, but larger Mean body length is of $1167.3 \mu \mathrm{m}( \pm 26.8 \mu \mathrm{m})$ and the mean body width is of $1708.9 \mu \mathrm{m}( \pm 41.2 \mu \mathrm{m})$. The size, shape and colour of the collected mite match with the original description (Fig. 2).
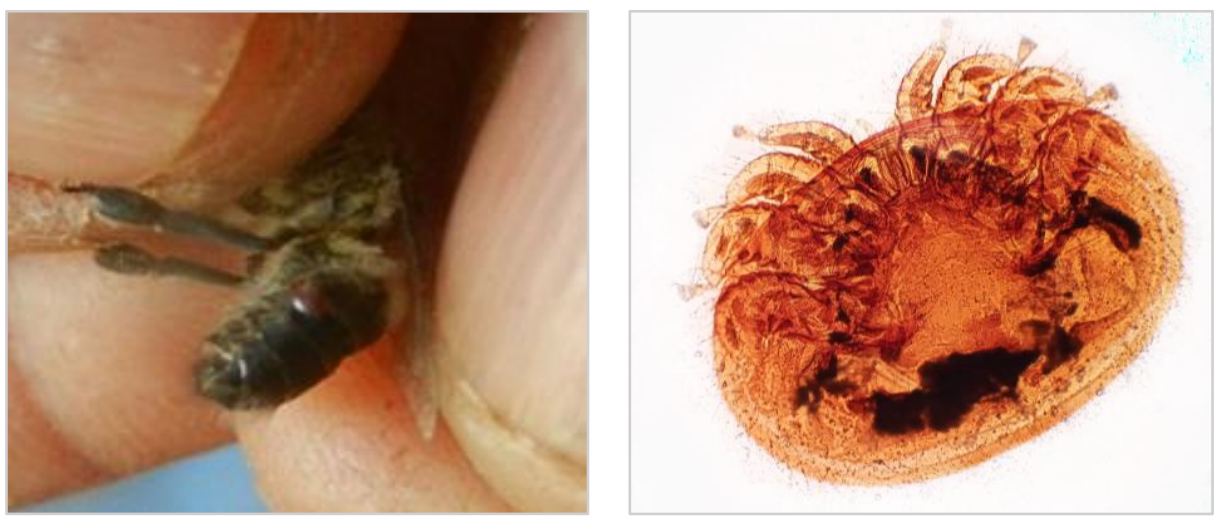

Figure 2. V. destructor collected from Palpa district, Nepal. Left: Female mite on adult $A$. cerana. Right: Dorsal enlarged view of the female mite

\section{4 | Data analysis}

Pearson's correlation coefficient ( $r$ ) was calculated between the population of varroa mites observed and temperature and humidity records. The data was analyzed through ANOVA of two different sites of population of varroa mites in nine-month periods with MS-Excel 2016.

\section{3 | Results}

A total of 498 varroa mites were collected from site-I $(n=279)$ and site-II $(\mathrm{n}=219)$. The prevalence of mite population was higher in March (site-I: 22.58\%, site-II: 21\%) and lower in September (site-I: 3.58\%, site-II: $3.2 \%$ ). Mites in brood cells were observed higher (site-l: $54.84 \%$, site-II: $52.51 \%$ ) than in adult bees (site-I: 10.39\%, site-II: $9.59 \%)$

The mite population was found higher in two years old bee hive (site-l) in comparison to mixed types of bee hives at site-II. The mite population was declined in April and May and increased in June. The monthly population of varroa mite was differed at site-I $(\mathrm{df}=$ $2,24, P=0.002)$ and site- $I I(d f=2,24, P=0.002)$. The prevalence of $V$. destructor is shown in Table 1.
As shown in Figure 3, the inner hive temperature and outer temperature ranged from $30^{\circ} \mathrm{C}$ to $34^{\circ} \mathrm{C}$ and $24^{\circ} \mathrm{C}$ to $32.4^{\circ} \mathrm{C}$, respectively. The relationship between population of varroa mite with inner and outer hive temperature did not differ significantly $(P=0.64$ and $P=0.16$, respectively). Inner hive temperature and outer temperature were found negatively correlated and positively correlated with mite population as $r=0.18$ and $r=-0.5$, respectively at site-I. Similarly, the relationship between population of mite with inner and outer hive temperature did not show significant difference $(P=0.08$ and $P=0.46$, respectively) at site-II. The temperature ranged from $30^{\circ} \mathrm{C}$ to $33.5^{\circ} \mathrm{C}$ in inner hives and $25.1^{\circ} \mathrm{C}$ to $32.3^{\circ} \mathrm{C}$ around outer hives. Inner and outer hive temperature were found negatively correlated to mite as $r=-0.08$ and $r=-0.27$, respectively.

At the site-I, population of varroa mite in relation to inner and outer hive humidity differed significantly $(P=0.02$ and $P=0.05$, respectively). The humidity ranged from $41 \%$ to $61 \%$ and $40 \%$ to $68 \%$, and inner and outer hive humidity found positively correlated with mite population as $r=0.74$ and $r=0.66$, respectively. The mite population with inner and outer hive humidity showed $\mathrm{P}$ value 0.14 and 0.39 , respectively. Humidity inside the hive ranged from $40 \%$ to $60 \%$ and outside the hive $41 \%$ to $65 \%$. Inner hive humidity and outer humidity were found positively correlated with mite population as $r=0.53$ and $r=0.33$ respectively at site-II (Fig. 4).

Table 1. Prevalence of $V$. destructor on base, brood cell and adult at site-I and II.

\begin{tabular}{|c|c|c|c|c|c|c|c|c|c|}
\hline \multirow[t]{2}{*}{ S.N. } & \multirow[t]{2}{*}{ Month } & \multicolumn{2}{|c|}{ Base (\%) } & \multicolumn{2}{|c|}{ Brood (\%) } & \multicolumn{2}{|c|}{ Adult (\%) } & \multicolumn{2}{|c|}{ Total (\%) } \\
\hline & & Site-I & Site-II & Site-I & Site-II & Site-I & Site-II & Site-I & Site-II \\
\hline 1. & February & 21.65 & 8.43 & 20.26 & 13.91 & 34.48 & 14.29 & 22.22 & 11.87 \\
\hline 2. & March & 22.68 & 16.87 & 20.92 & 24.35 & 31.03 & 19.05 & 22.58 & 21 \\
\hline 3. & April & 4.12 & 3.61 & 5.88 & 6.09 & 0 & 0 & 4.66 & 4.57 \\
\hline 4. & May & 11.34 & 22.89 & 11.11 & 7.83 & 13.79 & 0 & 11.47 & 12.79 \\
\hline 5. & June & 6.19 & 21.69 & 15.69 & 11.30 & 3.45 & 9.5 & 11.11 & 15.07 \\
\hline 6. & July & 16.49 & 12.05 & 9.15 & 12.17 & 6.90 & 28.57 & 11.47 & 13.70 \\
\hline 7. & August & 4.12 & 2.41 & 7.19 & 13.91 & 0 & 0 & 5.38 & 8.22 \\
\hline 8. & September & 8.23 & 3.61 & 1.31 & 3.48 & 0 & 0 & 3.58 & 3.2 \\
\hline 9. & October & 5.15 & 8.43 & 8.50 & 6.96 & 10.34 & 28.57 & 7.53 & 9.59 \\
\hline \multicolumn{2}{|c|}{ Total } & 34.77 & 37.90 & 37.90 & 52.51 & 52.51 & 9.59 & 279 & 219 \\
\hline
\end{tabular}




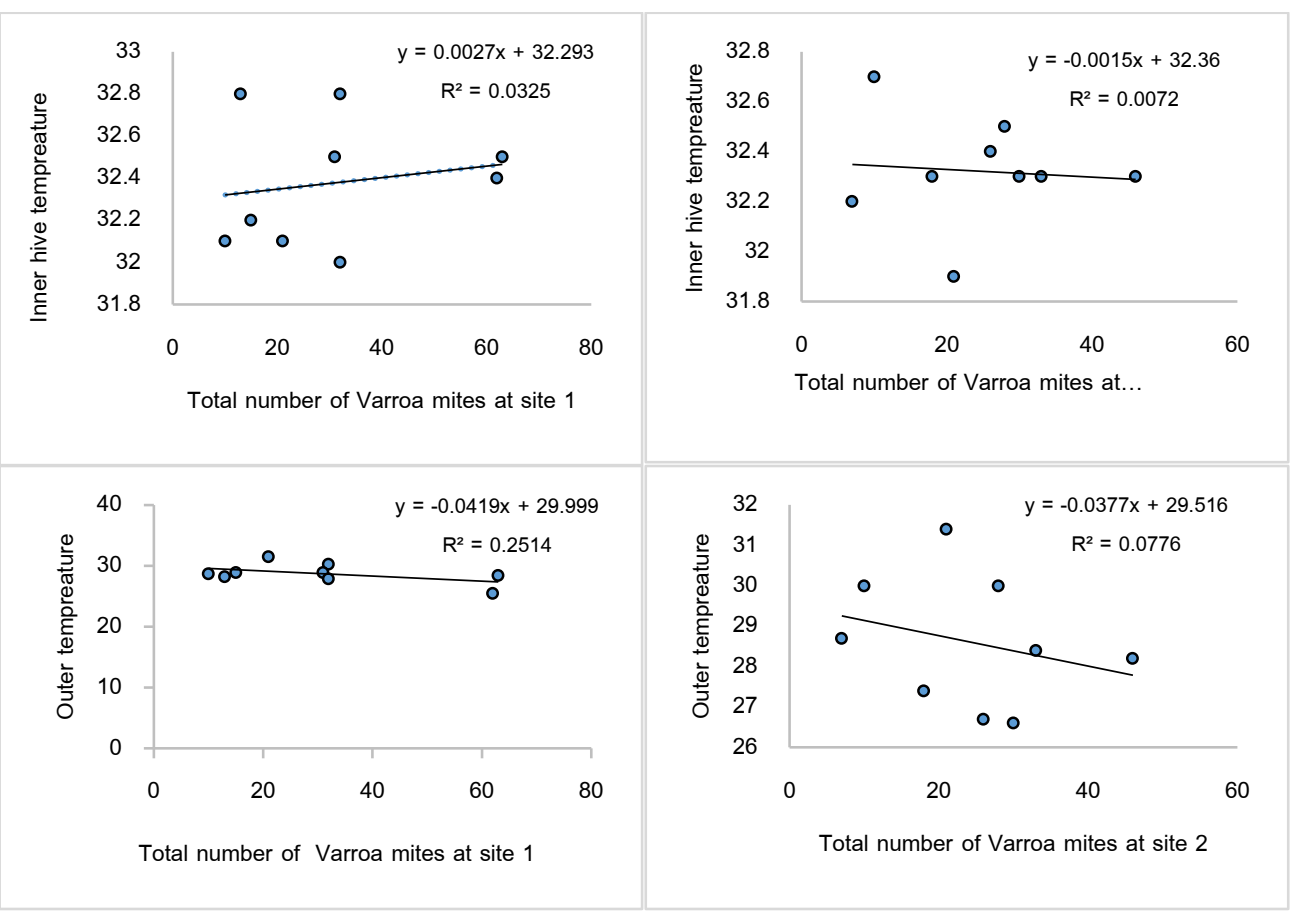

Figure 3. Population of $V$. destructor in relation to temperature prevalence and climatic factors on apiculture. Finding of $V$. destructor in A. cerana bees in Madanpokhara is an alarm to beekeepers of the area. The similar threats in Nepal are already noticed (Woyke 1985, Neupane 2009, and Shrestha et al. 2020). The varroa mite damage less in $A$. cerana due to its defense mechanisms (Peng et al. 1987)

Neupane (2009) reported availability of $V$. destructor on A. cerana which is a natural host at the same ecological

\section{4 | Discussion}

The Asian honey bee $A$. cerana is primarily parasitized by $V$. destructor and shifted from their primary host in north-east Asia (Navajas et al. 2010) infecting A. mellifera (Sanford et al. 2007) and is now a cosmopolitan species and causing serious threat to beekeeping industry. Despite this fact, some of the beekeepers were unaware of its impact in relation to its occurrence, niches and region might attract this mite to brood in large number rather than in $A$. mellifera. Their study found the lowest number of $V$. destructor in rainy (4.0 per sample), and the highest in spring (27.7 per sample) season in A. cerana colonies. The population of mites began to multiply from autumn and reached at higher damaging level in winter season. Although, it is in contrast to what have been shown by Fries et al. (1994) and Tibor \& Szabo (2003) who observed peak period of infestation by Varroa spp. between
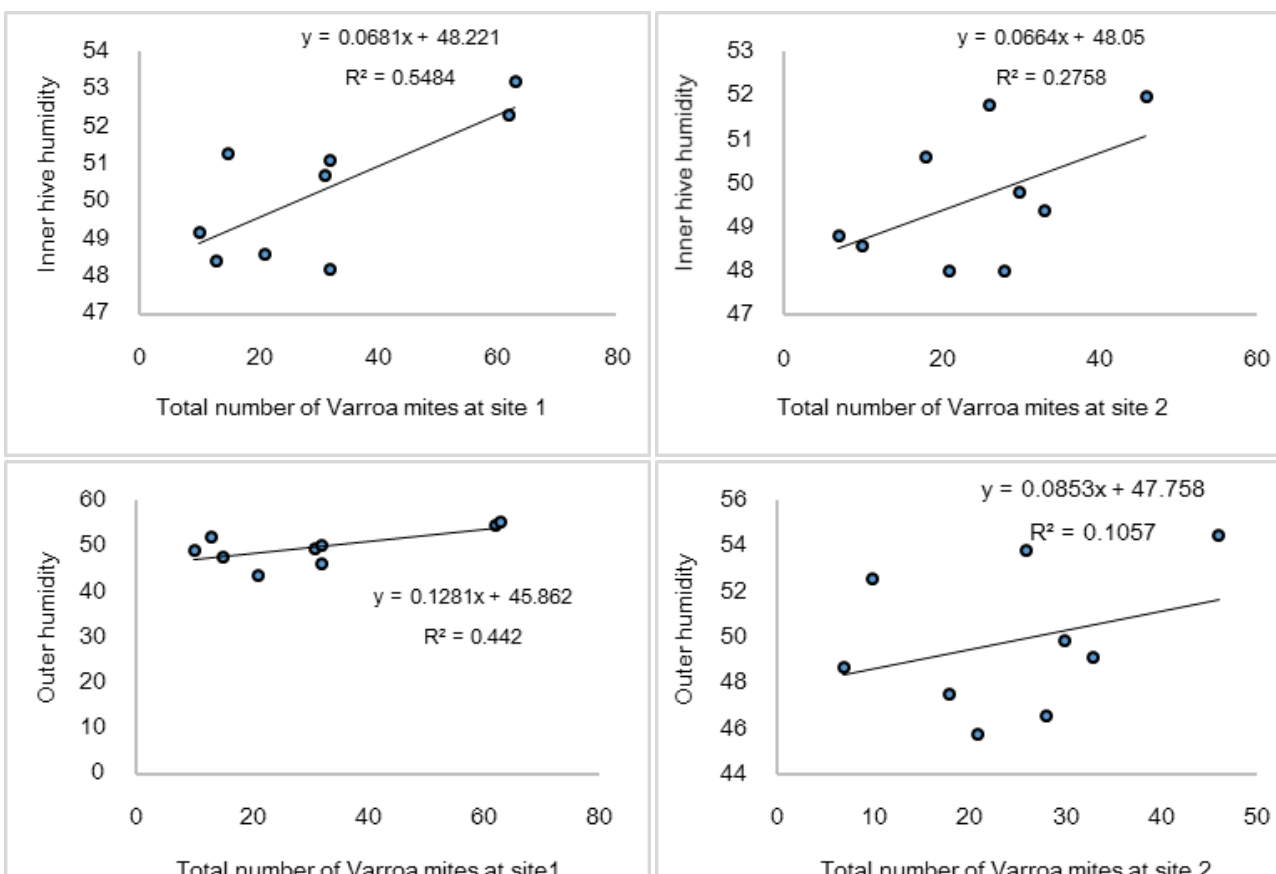

Total number of Varroa mites at site1

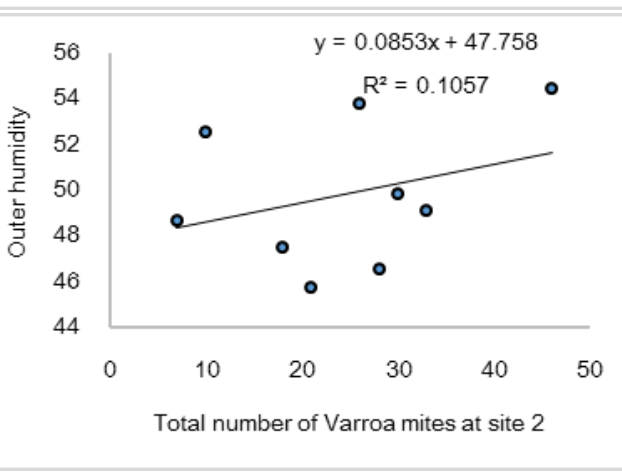

September to December in different parts of the world including Mattu and Sharma (2016) who concluded peak period in April. But, up to $90 \%$ of the varroa mites were observed into brood cells during the summer (Renz \& Rosenkranz 2001).

Furthermore, in some experimental conditions adult bees were found to be more favourable for varroa mites than larval stages (LeDoux et al. 2000, Zetlmeisl \& Rosenkranz 1994) but in other studies more mites were

Figure 4. Population of $V$. destructor in relation to humidity 
observed into the sealed brood cells in comparison to adult bees in natural conditions (Boot et al. 1993, Martin et al. 1998). In present study, the mites were observed higher in brood cells and lower in adult bees. Also, the mite population was found higher in two years old bee hives in comparison to mixed bee hives which possibly due to lack of management of old hives and mite's response to alteration in conditions of colonies. It is possible that variations in climatic conditions for countries other than Nepal are responsible for this discrepancy in seasonal fluctuation and prevalence of varroa mite. The reproductive process of $V$. destructor begins after abandoning adult worker bee or drone by adult females and then penetrating worker or drone brood cells (Gusman-Novoa et al. 1999). A few moments before cell operculation, the onset of mites in the cells of honeybees takes place when the bee brood reaches the last larval stage (De Jong 1997). Thus, varroa population is distributed among normal colonies with brood than adult bees. Drone brood about three to eight times more in comparison to worker brood is preferable to varroa (Fuchs \& Langenbach 1989). Therefore, the infestation of varroa mites may be due to production of drone brood during the sampling period. Furthermore, De Guzman \& Burgett (1991) explained that the infestation rate of the parasite cannot increase at the same rate as the host population.

The present findings showed humidity is correlated with mite's population whereas temperature was negatively correlated with mite's populations which indirectly corroborated the findings of Bonoan et al. (2014) with the observation, as there is a significant correlation between the densities of mite infection and climatic factors (temperature and humidity). The relationship between infestation rate of the mite in adult bees and environmental temperature was positively correlated (Pinto et al. 2015). In contrast, level of infestation of mite in colonies varied depending on the weather (season) and internal conditions of each colony (Koumad 2015). Opposite to Hou et al. (2016) who observed the mite infection in honeybee colonies was positively correlated with temperature but negatively correlated with humidity. In addition, the other influencing factors may be either equilibrium between mite receiver colonies from victim colonies more than one kilometer apart (Renz \& Rosenkranz 2001) or grooming behavior of honeybees, and management practices of bee hives. The honeybee, $A$. cerana, is subject to many viral infections persistently in honeybee populations between individuals of the same colony and between different colonies due to varroa mites, despite the lack of clinical signs. Environmental factors might play important role for disease outbreak resulting colony failure either through morbidity or mortality. It is worth to note that $V$. destructor might act as a vector or as an activator of replication of viruses. Therefore, further study is needed to understand the relationships among honeybees, varroa mites and viruses.

\section{5 | Conclusions}

The varroa mite population was reported higher in March and decreased in April and May and again increased in June. Mites were observed higher in brood cells than adult bees. Further, relationship among population of varroa mite with inner and outer hive temperature and humidity differed. varroa mites were not found detrimental to the colonies in this study but if remained unchecked, the population may become high enough to slow up the development of honeybees and honey production.

\section{Acknowledgements}

We extend our deep gratitude to the local people and beekeepers of Madanpokhara, Palpa for their sincere help and cooperation during field work also for necessary support and information. We thank Prof. Dr. Ranjana Gupta, former head, Central Department of Zoology, Tribhuvan University for providing necessary facilities to conduct this study.

\section{Authors' contributions}

Shrestha, N. performed the field study and analyzed the data. Both the authors wrote the manuscript and approved for the submission.

\section{Conflicts of interest}

Authors declare no conflict of interest.

\section{ORCID}

Ishan Gautam (D) https://orcid.org/0000-0002-3971-2895

\section{References}

Aggarwal, K. and Kapil, R. P. 1988. Seasonal population dynamics of Tropilaelaps clareae (Acari: Laelapidae) in Apis dorsata colonies. Progress in Acarology 2:283-286.

Amdam, G. V., Hartfelder, K., Norberg, K., Hagen, A. and Omholt, S. W. 2004. Altered physiology in worker honey bees (Hymenoptera: Apidae) infested with the mite Varroa destructor (Acari: Varroaidae): A factor in colony loss during overwintering? Journal of Economic Entomology 97:741-747. https://doi.org/10.1093/jee/97.3.741 
Anderson, D. 2000. Variation in the parasitic bee mite Varroa jacobsoni Oud. Apidologie 31:281-292.

Anderson, D. L. and Trueman, J. W. H. 2000. Varroa jacobsoni (Acari: Varroidae) is more than one species. Experimental and Applied Acarology 24:165-189.

Ball, B. V. 1989. Varroa jacobsoni as a virus vector, In: Cavalloro, R. (Ed.) Present status of varroatosis in Europe and progress in varroa mite control, Office for Official Publications of the European Communities, Luxembourg, pp 241-244.

Bernardi, S. and Venturino, E. 2016. Viral epidemiology of the adult Apis mellifera infested by the Varroa destructor mite. Heliyon 2(5): e00101. https://doi.org/10.1016/j.heliyon.2016.e00101

Bonoan, R., Goldman, R. R., Wong, P.Y. and Starks, P. T. 2014. Vasculature of the hive: heat dissipation in the honey bee (Apis mellifera) hive. Naturwissenschaften 101:459-465.

Boot, W. J., Calis, J. N. M. and Beetsma, J. 1993. Invasion of Varroa jacobsoni into honey bee brood cells: a matter of chance or choice? Journal of Apiculture Research 32:167-174.

Bowen-Walker, P. L., and Gunn, A. 2001. The effect of the ectoparasitic mite, Varroa destructor, on adult worker honey bee (Apis mellifera) emergence weights, water, protein, carbohydrate, and lipid levels. Entomologia Experimentalis et Applicata 101:207-217. https://doi.org/10.1046/j.1570-7458.2001.00905.x.

Buawangpong, N., Guzman, L. I., De Khongphinitbunjong, K., Frake, A. M., Burgett, M. and Chantawannakul, P. 2015. Prevalence and reproduction of Tropilaelaps mercedesae and Varroa destructor in concurrently infested Apis mellifera colonies. Apidologie 46:779-786.

Dandeu, J. P., Lux, M., Colin, M. E., Rabillon, J. and David, B. 1991. Etude immuno-chimique de l'hémolymphe d'abeille ouvrière adulte (Apis mellifera L.) saine ou infestée par Varroa jacobsoni Oud. Apidologie 22:37-42 (in French).

De Guzman, L. I. and Burgett, D. M. 1991. Seasonal abundance of the A. mellifera L. ectoparasites Acarapis dorsalis Morgenthaler and Acarapis externus Morgenthaler (Acari: Tarsonemidae) in Oregon. Bee Science 1:219-224.

De Jong, D. 1997. Mites: Varroa and other parasites of brood. In: Morse, R. A. \& Flottum, K. (Eds.) Honey bee pest, predators and diseases, The A. I. Root Company, OH, pp 279-328.

Delfinado-Baker, M. and Aggarwal, K. 1987. A new Varroa (Acari: Varroidae) from the nest of Apis cerana (Apidae). International Journal of Acarology 13(4):233-237. https://doi.org/10.10-80/01647958708683777.

Duay, P., De Jong, D. and Engels, W. 2003. Weight loss in drone pupae (Apis mellifera) multiply infested by Varroa destructor mites. Apidologie 34:61-65. https://doi.org/10.1051/-apido:2002052

Fries, I., Camazine, S. and Sneyed, J. 1994. Population dynamics of Varroa jacobsoni: a model and review. Bee World 75:15-28.

Fuchs, S. and Langenbach, K. 1989. Multiple infestation of Apis mellifera L. brood cells and reproduction in Varroa jacobsoni Oud. Apidologie 20:257-266.

Gregory, P. G., Evans, J. D., Rinderer, T. and De Guzman, L. 2005. Conditional immune-gene supression of honeybees parasitized by varroa mites. Journal of Insect Science 5:7-11. https://doi.org/10.1093/jis/5.1.7.

Gusman-Novoa, E., Valdame, R., Arechavaleta, M. E. and Sanches, A. 1999. Susceptibility of European and Africanized bees (Apis mellifera L.) to Varroa jacobsoni Oud. Apidologie, 30:173182.

Hou, C. S., Li, B. B., Deng, S. and Diao, Q. Y. 2016. Effects of Varroa destructor on temperature and humidity conditions and expression of energy metabolism genes in infested honeybee colonies. Genetics and Molecular Research 15(3):gmr8997. https://doi.org/10.4238/gmr.15038997.

Jamshidi, R., Yousefkhani, M. and Lotfi, A. R. 2009. Incidence rate of varroaris in honey bee colonies of eastern Azarbaijan Province, Northwestern Iran. Asian Journal of Animal and Veterinary Advances 4:342-345. https://doi.org/10.3923/ajava.2009.342.345

Khoury, D. S., Myerscough, M. R. and Barron, A. B. 2011. A quantitative model of honey bee colony population dynamics. PLoS ONE 6(4):e18491. https://doi.org/10.1371/journal.-pone.0018491

Koumad, S. 2015. Study of the population dynamic of Varroa destructor in Algeria. Journal of Humanities, Arts, Medicine and Sciences 1(2): 69-76.

LeDoux, M. N., Pernal, S. F., Higo, H. A. and Winston, M. L. 2000. Development of a bioassay to test the orientation behaviour of the honey bee ectoparasite Varroa jacobsoni. Journal of Apiculture Research 39:47-54.

Maidana, N. A., Benavente, M. A. and Eguaras, M. 2005. A model in differential equations to describe the mite Varroa destructor population dynamic in Apis mellifera colonies. Foro-Red-Mat: Revista electrónica de contenido matemático 16(9):1.

Martin, S. J., Hogarth, A., van Breda, J. and Perrett, J. 1998. A scientific note on Varroa jacobsoni Oudemans and the collaps of Apis mellifera L. colonies in the United Kingdom. Apidologie 29:369-370.

Mattu, V. K. and Sharma, I. 2016. Seasonal variation of ectoparasite mite Tropilaelaps clareae and Varroa jacobsoni on Apis mellifera. International Journal of Scientific Research 5(6):18-20.

Navajas, M., Migeon, A., Alaux, C., Martin-Magniette, M. L., Robinson, G. E., Evans J. D. et al. 2008. Differential gene expression of 
the honey bee Apis mellifera associated with Varroa destructor infection. BMC Genomics 9:301-311. https://doi.org/10.1186/1471-2164-9-301.

Navajas, M., Anderson, D. L., Guzman, L., Huang, Z.Y., Clement, J., Zhou, T. et al. 2010. New Asian types of Varroa destructor: a potential new threat for world apiculture. Apidologie 41:181-193.

Neupane, K. R. 2009. Honey bee mites and their population variation in Apis spp. during different seasons, Chitwan Nepal. Journal of Institute of Agriculture and Animal Science 30:159-166.

Peng, Y. S., Fang, Y., Xu, S. and Ge, L. 1987. The resistance mechanism of the Asian honeybee Apis cerana Fabr. to an ectoparasite mite Varroa jacobsoni Oudemanas. Journal of Invertebrate Pathology 19:54-60.

Pinto, F. A., Puker, A., Message, D. and Barreto, L. M. R. C. 2015. Infestation rate of the mite Varroa destructor in commercia apiaries of the Vale do Paraíba and Serra da Mantiqueira, Southeastern Brazilian Journal of Veterinary and Animal Science 67(2):631-635

Renz, M. and Rosenkranz, P. 2001. Infestation dynamics and reinvasion of Varroa destructor mites in honey bee colonies kept isolated and in groups. Apidologie 32:492-494.

Ritter, W. and Ruttner, F. 1980. Methods of diagnosis of Varroa Jacobsoni infestations. Allgemeine Deutsche Imkerzeitung 14:134-138.

Sanford, M. T., Demark, H. A., Cromroy, H. L. and Cutts, L. 2007. Featured Creatures: Varroa mite. University of Florida Institute of Food and Agricultural Science, USA.

http://creatures.ifas.ufl.edu/misc/bees/Varroa mite.htm

Shimanuki, H., Calderone, N. W. and Knox, D. A. 1994. Parasitic mite syndrome: the symptoms. American Bee Journal 134:827-828.

Shrestha, M., Wegener, J., Gautam, I., Singh, M., Schwekendiek, C., Bienefeld, K. 2020. Individual-level comparisons of honey bee (Hymenoptera: Apoidea) hygienic behavior towards brood infested with Varroa destructor (Parasitiformes: Varroidae) or Tropilaelaps mercedesae (Mesostigmata: Laelapidae). Insects 11(8):510. https://doi.org/10.3390/insects 11080510

Sumpter, D. J. T. and Martin, S. J. 2004. The dynamics of virus epidemics in Varroa-infested honey bee colonies. Journal of Animal Ecology 73:51-63.

Tentcheva, D. L., Gauthier, S., Jouve, L., Canabady-Rochelle, B., Dainat, F., Cousserans, M.E., et al. 2004. Polymerase chain reaction detection of deformed wing virus (DWV) in Apis mellifera L. and Varroa destructor. Apidologie 35:431-439.

Tibor, S. I. and Szabo, D. C. 2003. Varroa infestation levels of honeybee colonies characteristics in final year of breeding programme. American Bee Journal 143(10):798-802.
Wongsiri, S., Tangkanasing, P. and Sylvester, H. A. 1989. The resistance behavior of Apis cerana against Tropilaelaps clareae. Proceedings of the First Asia-Pacific Conference of Entomology, 8-13 November 1989, Chiang Mai, Thailand, pp 25-34.

Woyke, J. 1985. Tropilaelaps clareae Delfinado and Baker a serious pest of Apis mellifera L. in the tropics but not dangerous for Apiculture in temperate zone. American Bee Journal 125(7):497499.

Yang, X. and Cox-Foster, D. L. 2005. Impact of an ectoparasite on the immunity and pathology of an invertebrate: Evidence for host immunosuppression and viral amplification. Proceedings of the National Academy of Sciences 102:7470-7475. https://doi.org/10.1073/pnas.0501860102.

Zetlmeisl, K. and Rosenkranz, P. 1994. Varroa females in a bioassay: host recognition of honey bee larvae and adult bees. Apidologie 25:507-508.

\section{Cite this article as:}

Shrestha, N. and Gautam, I. 2020. Seasonal prevalence of Asian honeybee ectoparasitic mite Varroa destructor Anderson and Trueman, 2000 in Madanpokhara Apiaries, Palpa, Nepal. Nepalese Journal of Zoology 4(2):61-67. https://doi.org/10.3126/njz.v4i2.33885 